\title{
Prospecting for dimension stones in Greenland
}

\author{
Thomas V. Rasmussen and Hans Kristian Olsen
}

Dimension stones, or ornamental stones, are naturally occurring rocks that have properties that make them suitable for decorative exterior and interior use in the building industry. Large parts of Greenland should have a good potential for finding occurrences of valuable dimension stones, and the Geological Survey of Denmark and Greenland (GEUS) and Greenland Resources A/S (GRAS) therefore carried out prospecting in several parts of Greenland in the summers of 2001-2004. The project is mainly financed by the Government of Greenland, but recently the European Union and Nuup Kommunea have also contributed.

\section{Dimension stone exploration in Greenland}

All Nordic countries with exposed crystalline basement have had large stone industries for decades, or even centuries. For example, the annual Norwegian production of dimension stones and related materials had a value of about 100 million Euros in 2003; even Denmark has a well-established stone production and export from quarries on Bornholm. Greenland currently occupies an unfavourable position in this context, with only a small production of unpolished rock slabs, kerbstones and road material for local use; at present there is no export at all of natural stone products. However, a small company in Nuuk (Grønlandsk Produktion A/S) has recently invested in facilities to process and polish natural stone, so with interest from local industry there is a good prospect for future dimension stone production.

The development of a stone industry in Greenland is compatible with the existing infrastructure for many reasons: (1) natural stone resources are plentiful and can be easily inspected because of the high degree of exposure in Greenland, (2) the production only requires relatively low-cost investments, (3) areas of interest are often easily accessible from the sea, (4) the Government of Greenland favours new industrial initiatives, (5) the international dimension stone market demands a large variety of rock types, and special varieties - some of which are already known in Greenland - are generally considerably more valuable than common rock types, and (6) the world market price for large blocks of special rock types is in the range of 800-1200 Euros per cubic metre; with such price levels the financial costs of transport-

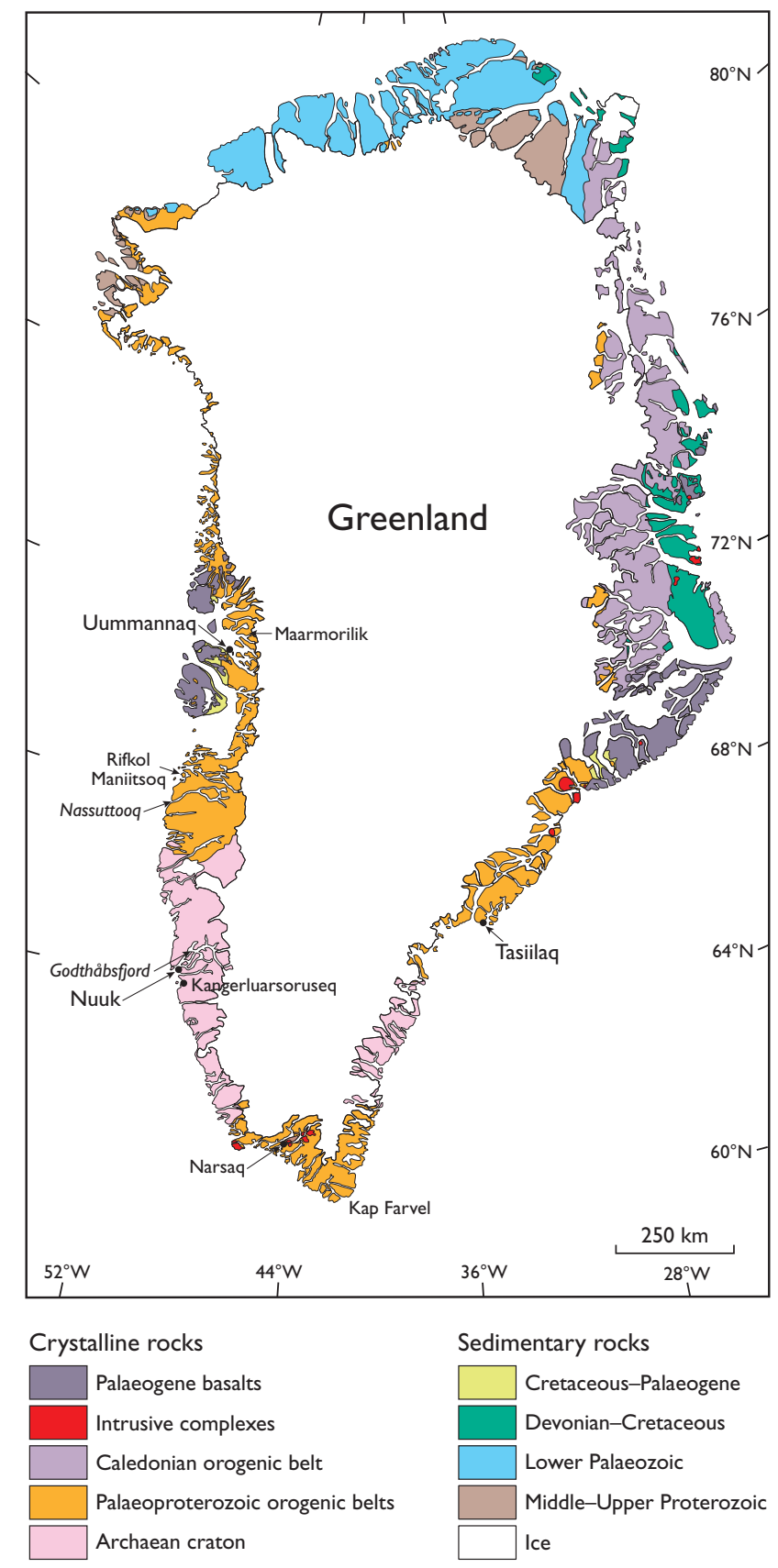

Fig. 1. Simplified geological map of Greenland showing place names and areas prospected for dimension stones. The Gardar Province of South Greenland, including the Eriksfjord Formation and the Ilímaussaq alkaline complex, is situated between Narsaq and the Inland Ice. 

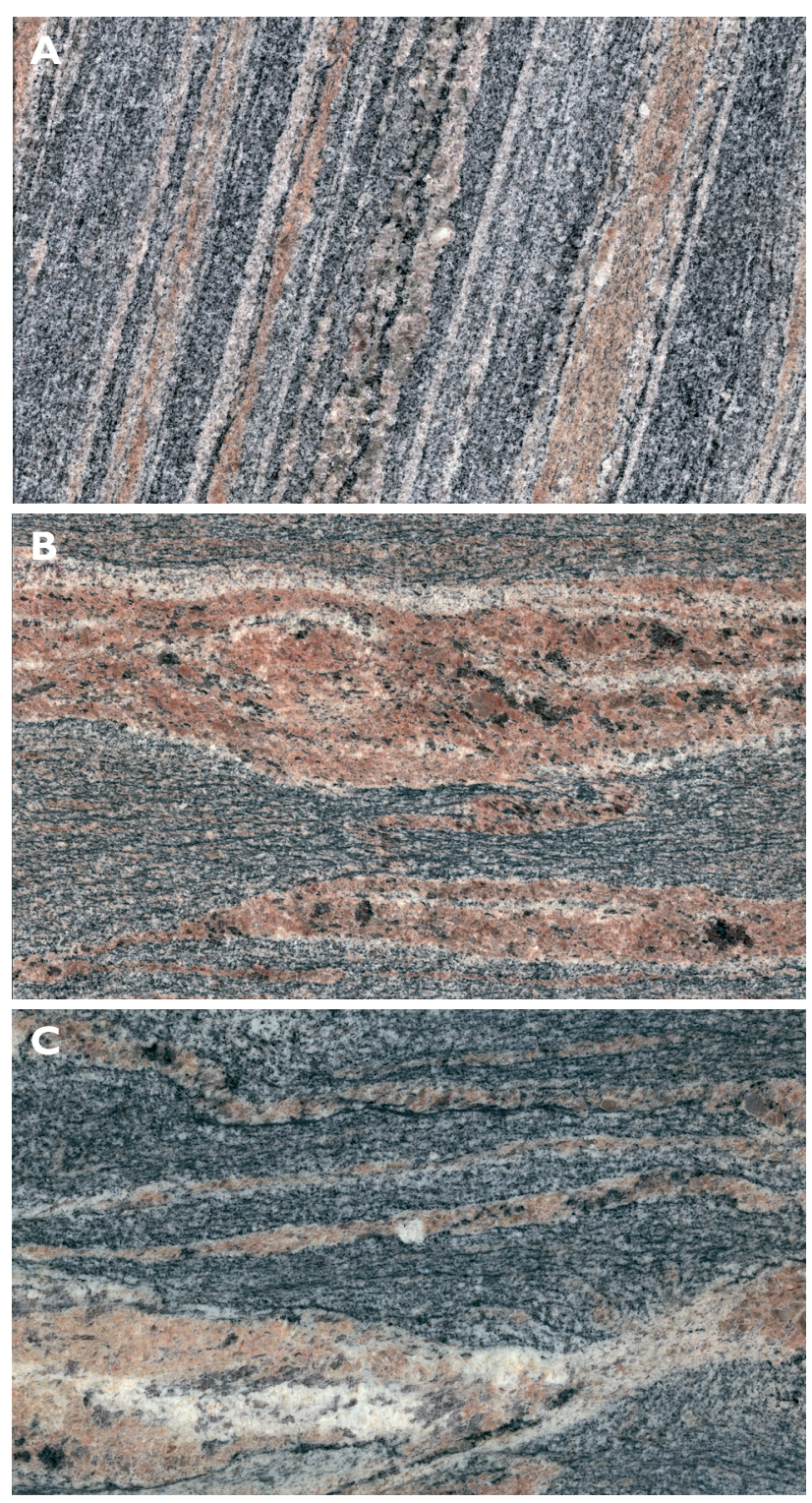

Fig. 2. A-C: Polished slabs of migmatitic biotite gneisses from Nassuttooq. Width of slabs $30 \mathrm{~cm}$.

ing the blocks from Greenland to worldwide markets only present a minor problem.

There is currently a trend of depopulation of villages in Greenland due to a shortage of local economic opportunities. The potential benefits of establishing dimension stone quarries near local communities would help sustain the existing smaller villages in Greenland, which has a high priority on the political agenda. The dimension stone industry is environmentally friendly and labour intensive, and the value of the mined product can be high, making exploitation of the natural resource both socially and environmentally beneficial.

\section{Previous dimension stone activities in Greenland}

Greenland previously hosted a commercial quarry at Maarmorilik in central West Greenland (Fig. 1), where marble from the Palaeoproterozoic Mârmorilik Formation was excavated and exported to Denmark between 1968 and 1972. Several well-known public and private buildings in Denmark have floors or facades of this Greenlandic marble. The Igaliko sandstone from the Mesoproterozoic Eriksfjord Formation in South Greenland (Fig. 1) has been exploited for local use as building stones, e.g. in the settlement of Igaliko near Narsaq.

Since 1974, however, and up to 2000 very little effort has been directed towards prospecting for dimension stone in Greenland. The exception was a reconnaissance study in 1990, covering the west coast of Greenland between Uummannaq and Kap Farvel (Garde et al. 1991; Gothenborg et al. 1994).

\section{Criteria for suitable dimension stone localities}

A good dimension stone locality must contain an unusual and attractive rock type of high technical quality, which can fetch a high price on the international market. The fracture density should be low, with no more than three sets of fractures that must be perpendicular to each other, so it is possible to produce blocks of about $1 \times 2 \times 3 \mathrm{~m}$ in size. Furthermore, the locality must contain a large volume of homogeneous rock that can easily be quarried without removal of excessive overburden or quarrying below sea level, and without hazards such as danger from falling blocks. To minimise the cost of local transport, the site must be accessible from the sea. In spite of these strict criteria Greenland offers a large potential, not least in view of its varied bedrock geology, suitable topography, excellent exposure and very long accessible coastline.

\section{Prospected areas in 2001-2004}

The target areas for the surveys in 2001-2004 were chosen with background in the previous reports on dimension stones and the general criteria listed above, the geological literature, and field observations by geologists from the Survey in recent years. The level of the existing local infrastructure was also taken into account. The main target areas were located in the Nassuttooq (Nordre Strømfjord) and Nuuk regions in central West Greenland, the Gardar Province in South Greenland and around Tasilaq in East Greenland (Fig. 1). In each area, potential dimension stone localities were mapped and very large samples were collected for testing, cutting and polishing. 


\section{Central West Greenland}

In the central and inner parts of Nassuttooq the primary targets were occurrences of large areas of migmatitic biotite gneiss and orthopyroxene gneiss (charnockite) with low fracture density (Rasmussen 2003; Rasmussen \& Olsen 2003). About ten such localities of migmatitic biotite gneiss with low fracture density were identified in the Nassuttooq region. The migmatitic biotite gneiss has spectacular textures with pinkish red and grey colours (Fig. 2A-C). Furthermore, several varieties of orthopyroxene gneiss (Fig. 3A, B) with low fracture density were located in the Nassuttooq region and on the islands Rifkol and Maniitsoq just off the coast north of Nassuttooq.

\section{Nuuk-Kangerluarsoruseq region}

In the region around Nuuk, the capital of Greenland, and nearby areas to the south several interesting rock types were located. In Kangerluarsoruseq (Færingehavn) south of Nuuk a massive olivine dolerite/gabbro and an anorthosite were sampled, as well as a leucogabbro with attractive iridescence in the feldspars (peristerite and labradorite). Closer to Nuuk there are several localities with augen gneiss and granite, both with low fracture densities. Just east of Nuuk on the island of Sermitsiaq there is a potential for dark green, brown and black ultramafic metamorphic rocks.

\section{South Greenland}

In South Greenland the main focus of the 2001-2004 surveys was on the Ilímaussaq alkaline complex and the sandstones of the Eriksfjord Formation (Kalvig et al. 2002; Rasmussen 2003; Rasmussen \& Olsen 2003). The Ilímaussaq alkaline complex has the advantage that several unique and attractive rock types with very spectacular colours are exposed within a small area. Two types of kakortokite (Fig. 3C) and naujaite (Fig. 3D) were sampled. The main challenge of the Ilímaussaq alkaline complex is to locate areas with a sufficiently low fracture density, as many exposures are heavily fractured in the surface outcrops. The Eriksfjord Formation close to the Ilímaussaq alkaline complex hosts several occurrences of colourful sandstones. The common red type (Fig. 4A) has a good potential because many old buildings in Europe built of red sandstone are in need of restoration, and suitable sandstone resources in Europe are gradually becoming exhausted. The sandstones from the Eriksfjord Formation are quartz-cemented, which is a distinct advantage compared to the more common calcitecemented sandstones. Quartz-cemented sandstones can be used in all environments because they are resistant to chemi-
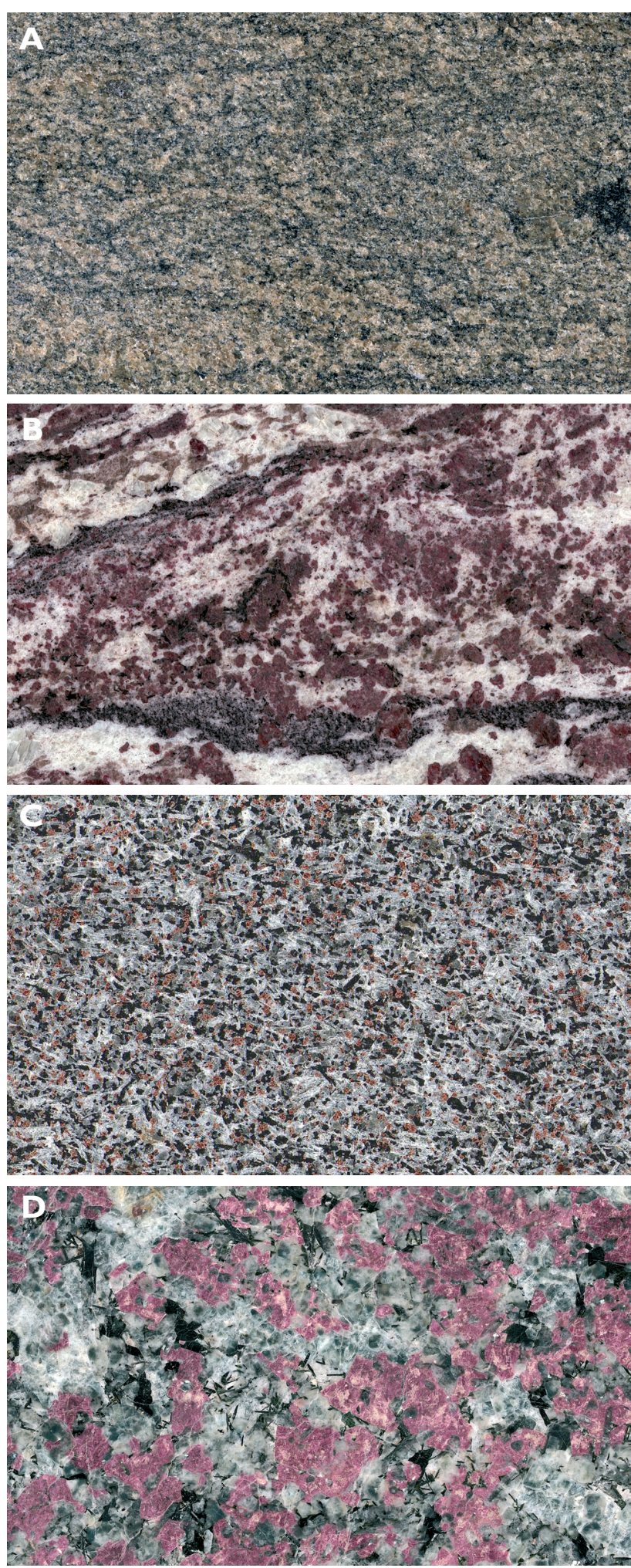

Fig. 3. A: Polished slab of homogeneous orthopyroxene gneiss from Nassuttooq. B: Polished slab of garnet-biotite-quartz paragneiss from Nassuttooq. C: Polished slab of kakortokite from the Ilímaussaq alkaline complex of South Greenland. D: Polished slab of naujaite from the Ilímaussaq alkaline complex of South Greenland. Width of slabs $20 \mathrm{~cm}$. 

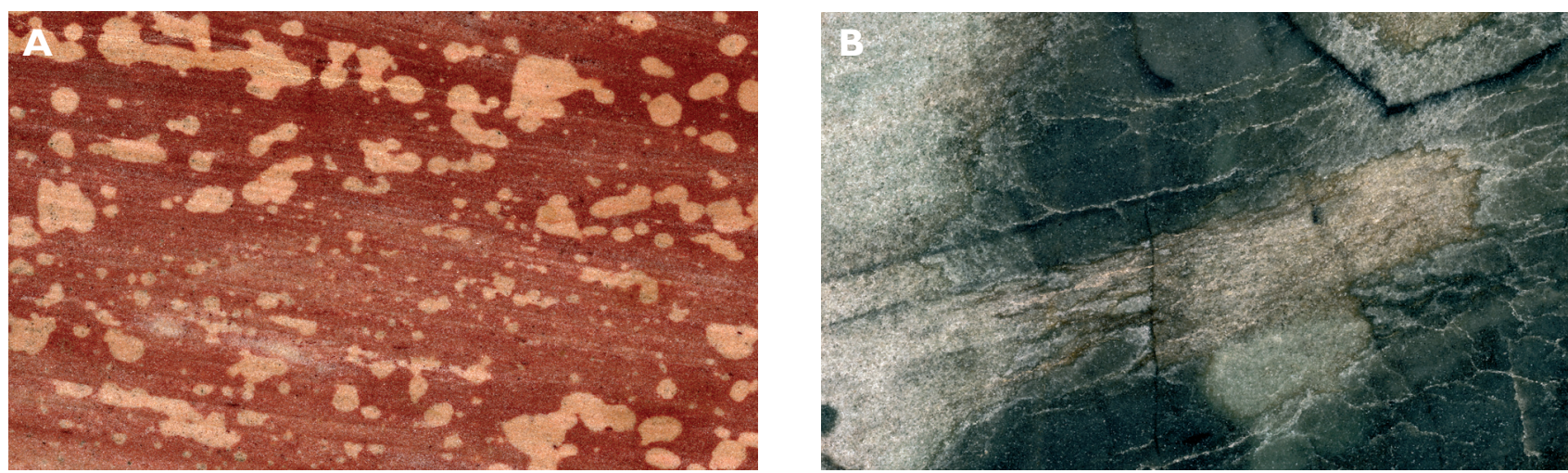

Fig. 4. A: Polished slab of red sandstone from the Eriksfjord Formation in South Greenland. B: Polished slab of massive blue-green quartzite from the Eriksfjord Formation in South Greenland. Width of slabs $20 \mathrm{~cm}$.

cal weathering, and also takes polishing very well. The red sandstones of the Eriksfjord Formation are intruded locally by Gardar dolerite dykes, which have baked the sandstone close to the dykes and transformed it into a massive quartzite with an attractive blue-green colour (Fig. 4B). Although the volume of this lithological variety is limited, it has promising possibilities on the international dimension stone market.

\section{East Greenland}

In the Ammassalik area of East Greenland large outcrops of massive pink granite with extremely low fracture density have been located (Kalvig et al. 2002; Rasmussen 2003).

\section{Current and future dimension stone projects}

The next steps for dimension stone prospecting in Greenland will be promotion of the collected rocks to large international stone companies and continued field prospecting in Greenland.

In 2004, the dimension stone project was granted 50000 Euros from the EU's Northern Periphery Programme (NPP). Under the NPP the Nordic countries (Sweden, Norway, Finland and Denmark) have formed a working group (PNASTINA), which aims at promoting the natural stone industry in northern Europe. Since large international stone companies are already established in Finland, Norway and Sweden, the PNASTINA group provides an important con- tact for Denmark and Greenland to the international dimension stone market.

The plan for 2005 is to continue the prospecting in the Godthåbsfjord region of southern West Greenland and in the Gardar province in South Greenland.

\section{Acknowledgements}

The Bureau of Minerals and Petroleum (BMP), Nuup Kommunea, Sulisa $\mathrm{A} / \mathrm{S}$ and the EU (Northern Periphery Programme) provided financial support for the project.

\section{References}

Garde, A.A., Bugnon, C. \& Gothenborg, J. 1991: Ornamental stones in West and South Greenland. Rapport Grønlands Geologiske Undersøgelse 152, 50-55.

Gothenborg, J., Garde, A.A. \& Bugnon, C. 1994: Greenland ornamental stone resources. The 1990/91 ornamental stone project. Open File Series Grønlands Geologiske Undersøgelse 94/2, 143 pp.

Kalvig, P., Knudsen, C.N. \& Rasmussen, T.V. 2002: Potentialer for facadesten og skærver i Grønland. Danmarks og Grønlands Geologiske Undersøgelse Rapport 2002/11, 104 pp.

Rasmussen, T.V. 2003: Dimension stone prospecting in West, South and East Greenland 2002. Danmarks og Grønlands Geologiske Undersøgelse Rapport 2003/8, 60 pp.

Rasmussen, T.V. \& Olsen, H.K. 2003: Dimension stone prospecting in West and South Greenland 2003. Danmarks og Grønlands Geologiske Undersøgelse Rapport 2003/107, 67 pp.

\section{Authors' addresses}

T.V.R., Geological Survey of Denmark and Greenland, Øster Voldgade 10, DK-1350 Copenhagen K, Denmark. E-mail: tvr@geus.dk H.K.O., Greenland Resources. Present address: NunaOil A/S, Tuapannguit 38, P.O. Box 579, DK-3900 Nuuk, Greenland. 